\title{
THE INVESTIGATION OF JURNAL KEPEMIMPINAN PENDIDIKAN SITUATIONAL LEADERSHIP, AND WORK MOTIVATION ON KINDERGARDEN TEACHER PERFORMANCE

\section{Yayan MUDIYANTUN}

Universitas Muhammadiyah Prof. DR. HAMKA,

yayanmudiyantun@gmail.com

\begin{abstract}
The purpose of this study was to investigate the influence of the principal's situational leadership on teacher performance; the influence of work motivation on teacher performance; and the influence of the principal's situational leadership on work motivation. The research employed a causal survey research and path analysis technique. The sample of 103 kindergarten teachers of Tanggerang regency was taken by using proportional random sampling. The results have shown that 1) Path coefficient value of the principal's situational leadership and the teacher performance is 0.440 with the probability significance value $\rho_{\times 3 \times 1}=0.000$. It means that the principal's situational leadership has a significant effect on teacher performance. 2) Path coefficient value of work motivation and the teacher Performance is 0.166 with the probability significance value $\rho \times 3 \times 1=0.005$. It indicates that work motivation has a significant effect on teacher performance. 3) Path coefficient value of situational leadership and teacher work motivation is 0,598 with probability significance value $\rho \times 3 \times 1=0.000$. It implies that the principal's situational leadership has a significant effect on work motivation. Based on the research findings, it can be inferred that leadership style has a major role to develop work motivation and performance that have a positive impact on the quality of individuals in an organization
\end{abstract}

Keywords: Situational Leadership; Work Motivation; Teacher Performance; school principal

\section{ABSTRAK}

Penelitian ini bertujuan untuk meneliti pengaruh langsung kepemimpinan situasional kepala sekolah terhadap kinerja guru; pengaruh langsung motivasi kerja terhadap kinerja guru; dan pengaruh langsung kepemimpinan situasional kepala sekolah terhadap motivasi kerja guru. Penelitian ini merupakan penelitian kuantitatif dengan menggunakan metode penelitian survey kausal dan teknik analisis jalur. Sampel penelitian berjumlah 103 guru Taman Kanak-Kanak yang ada di Kabupaten Tangerang yang diambil secara acak. Hasil penelitian menunjukkan bahwa: 1) Nilai koefisien jalur variabel kepemimpinan situasional kepala sekolah dengan variabel kinerja guru adalah 0,440 dengan nilai probabilitas signifikansi $\rho_{x 3 x 1}=0,000$. Hal ini menunjukkan kepemimpinan situasional kepala sekolah berpengaruh signifikan terhadap kinerja guru. 2). Nilai koefisien jalur variabel motivasi kerja dengan variabel kinerja guru adalah 0,166 dengan nilai probabilitas signifikansi $\rho_{x 3 x 1}=0,005$. Hal ini menunjukkan motivasi kerja berpengaruh signifikan terhadap kinerja guru. 3). Nilai koefisien jalur variabel kepemimpinan situasional kepala sekolah $\left(X_{1}\right)$ dengan variabel motivasi kerja guru $\left(X_{2}\right)$ adalah 0,598 dengan nilai probabilitas signifikansi $\rho_{x 3 x 1}=0,000$. Hal ini menunjukkan kepemimpinan situasional kepala sekolah berpengaruh signifikan terhadap motivasi kerja. Dari hasil penelitian ini menyimpulkan bahwa gaya kepemimpinan mempunyai peran penting dalam meningkatkan motivasi kerja dan kinerja yang berdampak pada kualitas individu dalam sebuah organisasi. 


\section{Kata Kunci: Kepemimpinan Situasional; Motivasi Kerja; Kinerja Guru; Kepala sekolah}

\section{INTRODUCTION}

Schools as educational providers, consist of various elements of resources that must be managed and utilized properly in achieving the vision and mission of the school. Related to that, the role of teachers is one component that occupies a central position and is very strategic in the education system. Teachers are the dominant factors in relation to improving the quality of education, because teachers are an integral part of the education system. Overall the teacher is directly involved in the teaching and learning process, including playing a direct role in teaching and educating. Thus, the teacher's component determines the implementation of quality education. From teachers who are competent, professional and have a good personality, teaching and learning activities can take place smoothly and with quality.

From the description above it can be understood, that the effectiveness of teacher performance is the key that must be worked on. Teacher performance is the work of teachers who are reflected in designing teaching programs or preparing teaching plans, implementing teaching interpersonal relations, and in evaluating learning outcomes. The quality of teacher performance can be viewed in terms of process and results. From the aspect of the teacher process it is said to be successful if it is able to involve most of the students actively, physically, mentally, or socially in the learning process. Teacher performance is the most important part in improving the quality of education; therefore assessment of work together is something that needs to be paid attention seriously, especially by principals and supervisors.

Many factors influence the teacher's performance in carrying out his professional duties. Among these factors are work motivation, job satisfaction, leadership, school climate and other factors in order that the teachers encourage doing the performance as well as possible. Likewise, those that affect teacher performance include factors, meaningful leadership ability to motivate the performance of subordinates. A school principal as an education leader faces responsibility for improving the performance of the teacher he leads. For that, he must have adequate preparation, both mentally and psychologically in carrying out his duties, especially in dealing with the problems and challenges he faces. Principal leadership needs to provide comfort for teachers and students in their schools. The success of school organizations depends on the leadership role of the school principal. Kelley, Thornton, and Daugherty (2005) emphasized that leadership education may be likely the one of the most essential single determinant of an effective learning environment. The leadership style that is applied by the principal will be very influential in determining the direction and policies of education. For this purpose, principals must be able to mobilize and empower all potential in the organization, related to carrying out various programs, processes, evaluations, curriculum development, learning in schools, extracurricular activities, processing of teaching staff, facilities and infrastructure, service to students 
and parents, relationships to the community to the creation of a conducive, safe, comfortable and orderly school climate in the learning process.

Fullan (2002) points out that "Only principals who are equipped to handle a complex, rapidly changing environment can implement the reforms that lead to sustained improvement in student achievement". It is indeed true that principals must deal with the various levels of skills and abilities of their faculty and a continuity of divergent situations within today's complex school environment. The principal does not only play a role in supervising and motivating teachers. The role of the principal does not only supervise the teacher by assessing his performance, but he also plays a role in moving the teacher to do the work voluntarily. Here the role of the Principal in the lead needs to be tested including work motivation that must be based on sensitivity and good consideration for human relations and the completion of tasks. According to Hidayat and Machali (2010, p. 82), formulating leadership is the ability to move, influence, motivate, invite, direct, advise, foster, guide, train in ordering, governing, prohibiting and even punishing all organizational resources to achieve goals desired effectively and efficiently. Sulistiyani (2008) defines leadership as a person's work on how to direct (direct) others.

From this opinion, leadership is the ability of a leader to influence and move others to work together to achieve a group goal. Leadership is also the ability to obtain consensus of organizational members in carrying out management tasks so that organizational goals are achieved. Thus, the essence of leadership consists of: (1) influencing others to do something, (2) getting consensus or a job, (3) achieve management objectives, and (4) related to the purpose of obtaining mutual benefits.

One type of leadership is situational leadership. This situational leadership emphasizes the personal characteristics of leaders and situations, expresses and tries to measure or estimate this person, and helps leaders with useful behavioral guidelines based on a combination of personality possibilities and situational (Wahjosumidjo, 2011). This situational leadership focuses on the commitment and capacity of organizational members. The increasing commitment and capacity of members is considered to produce greater effort and productivity and will be the outcome expected by an organization. In addition to the principal's situational leadership, the teacher's performance is also influenced by motivation in the teacher. Many factors influence human motivation in working, among others, that humans have a set of needs, ranging from the highest needs, self-actualization. One of the factors that influence work motivation is one of leadership. Thus, it can be emphasized that leadership can be interpreted as the ability to motivate subordinates.

Work motivation as an aspect in achieving quality education goals is very necessary in teaching and learning activities. Motivation is a driver that can convert energy in the teacher into the form of a real activity to achieve certain goals in learning. Teachers who do not have motivation in working cannot do their jobs well Thus, it can be concluded that the low motivation of the teacher's work will have an impact on the low performance of teacher performance which can have implications for the low student learning outcomes. Under these circumstances, the aim of this study was to 
investigate the effect of the principal's situational leadership and work motivation on the performance of Kindergarten teachers in Tangerang Regency.

\section{METHOD}

This is a quantitative research using a causal survey research method with path analysis technique. Survey research is research that takes a sample of a population using a questionnaire as the main data collection tool. Survey research is research that takes samples from a population by using questionnaires as the main data collection tool (Singarimbun and Effendi, 2010). The sample in this study was 103 kindergarten teachers taken randomly. The variables in the study consisted of the effectiveness of the principal's situational leadership as a variable $\left(\mathrm{X}_{1}\right)$, motivation teacher achievement as a variable $\left(\mathrm{X}_{2}\right)$, and teacher competency as a variable $\left(\mathrm{X}_{3}\right)$.

The research design is as follows:

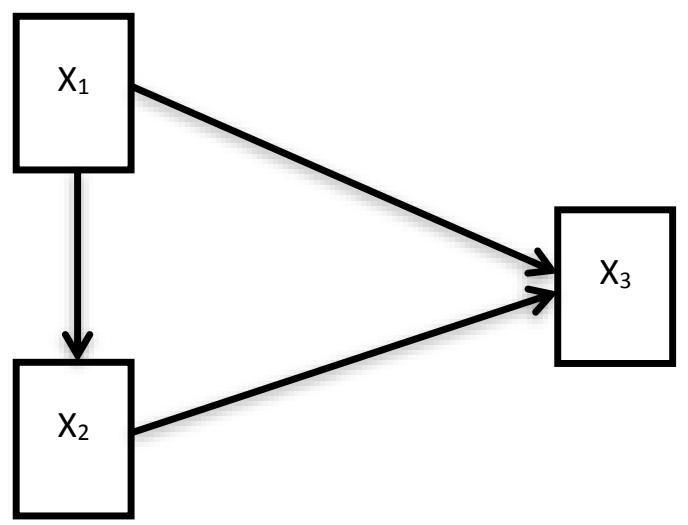

Figure 1. Research Design

Note:

$\mathrm{X}_{1}$ : Situational leadership

$\mathrm{X}_{2}$ : Work motivation

$\mathrm{X}_{3}$ : Teacher performance

\section{RESULT AND DISCUSSION}

The results of the study show the statistical values of each variable and the level of the relationship between variables as following description: The results of the study are described as follows:

\section{The effect of the principal's situational leadership on teacher performance}

Leadership is a person's ability to move subordinates so they want to work voluntarily to achieve goals. Whereas what is meant by situational leadership of a school principal is the ability of a principal to influence the behavior of others to think and behave in the framework of formulating and achieving organizational goals in certain situations. The situational approach in this leadership holds that the effectiveness of leadership depends on the compatibility between personal, task, power, attitude and perception. Managerial applications are supportive style, directive style, participatory style, and achievement-oriented style. The principal as a formal leader in the education environment at school 
should have a broad view and future insight to carry out the school's vision and mission. Therefore, the Principal is required to develop managerial skills and knowledge and can apply his situational leadership in contributing teacher performance.

Teacher performance can be interpreted as achievement achieved by the teacher after carrying out his duties as a teacher. Teacher performance is closely related to the success of organizational goals (educational success) where the teacher is the main actor. Therefore, teachers are required to always improve their performance. Teacher performance can be seen from the results or achievements of the teacher in carrying out his profession as an educator especially in his duties as a teacher. Optimal teacher performance will be achieved, if there is support from the optimal Principal leadership. In this case, situational leadership can help optimize teacher performance, because the Principal is required to work well with the teacher.

Based on the results of the $t$ test analysis, it shows the $t$ value is 5.488 . This $t$ value is then compared with the $t$ table value with $\mathrm{df}=101$. It obtained the value of 1.984. It turns out that $\mathrm{t}$ value is greater than $\mathrm{t}$ table $(5,488>1,984)$. Likewise with a significance level (p-value), it is known that the significance probability value (Sig.) $=0,000$. This means that the value of $\operatorname{Sig}<\alpha$ value $(0,000<0,05)$, it can be concluded that $\mathrm{H}_{0}$ is rejected and $\mathrm{H}_{1}$ is accepted. Based on the analysis of the correlation coefficient $\left(\mathrm{r}_{\mathrm{xy}}\right)$ between the principal's situational leadership $\left(\mathrm{X}_{1}\right)$ and the teacher's performance $\left(\mathrm{X}_{3}\right)$, it obtained the value of 0.479 with Sig. (2-tailed) of 0,000 . This means the value of Sig. $(0,000)<\alpha$ (0.05) with coefficient value of 0.479 . Thus it can be concluded that between situational leadership principals and teacher performance has a significant relationship with the moderate / sufficient category.

The results of this study are in accordance with the opinions expressed by Mulyasa in Barnawi and Arifin (2012), which states that the style of leadership influences employee performance to increase work productivity so as to achieve goals. By using the telling, selling, participating, and delegating approaches, teachers will carry out their teaching tasks well. In addition, this is in accordance with the opinion of Yamin and Maisah (2010), the determinants of the success of a leader include leadership techniques, namely how a leader is able to create a situation that causes the person he leads arises awareness to carry out what is desired by a leader. Leadership style, directly or indirectly has a positive influence on teacher improvement. Situational leadership style is considered by management experts as a style that is very suitable to be applied at this time. While for subordinates who belong to the level of maturity, namely subordinates who are incapable but willing, then this style of leadership is still directive, because it is less capable, it also provides supportive behavior.

\section{The effect of work motivation on teacher performance}

Motivation that is owned by a person can be used as a reference in carrying out activities to achieve goals. Motivation is an encouragement from both inside and outside of a person to carry out a series of efforts to meet the needs and achieve the desired goals. As an encouragement, motivation will provide a good stimulus to someone to fulfill their needs so that the goals that have been aspired can be 
achieved. One of the forms of motivation is the desire to achieve. Achievement needs are motives that can be distinguished in contrast to other needs. A person who is considered to have motivation, he will do a series of efforts in order to outperform the others. The connection in the field of education, motivation can also be used as a reference for teachers to improve the quality of performance. Not just teaching alone, the desire to direct behavior on efforts to achieve certain achievements based on perfection in a person also needs to be owned by a teacher.

Based on the results of the t-test analysis, it shows the value of $t$ value of 3.506 . This $t$ value is then compared with the value of $t$ table with df 101 obtained by the value of 1.984 . after comparing it turns out that $t$ count is greater than $t_{\text {table }}(3,506>1,984)$. Likewise with a significance level ( $p$-value), it is known that the significance probability value (Sig.) $=0.001$. This means that the value of $\mathrm{Sig}<\alpha$ value $(0.001<0.05)$, it can be concluded that $\mathrm{H}_{0}$ is rejected and $\mathrm{H}_{2}$ is accepted. It indicated that work motivation had a significant effect on the performance of Kindergarten teachers in Tangerang Regency. The correlation coefficient $\left(\mathrm{r}_{\mathrm{xy}}\right)$ between work motivation $\left(\mathrm{X}_{2}\right)$ and teacher performance $\left(\mathrm{X}_{3}\right)$ obtained a value of 0.329 with Sig. (2-tailed) of 0.029 . This means the value of Sig. $(0.001)<\alpha(0.05)$. Thus it can be concluded that the work motivation with teacher performance has a relationship with the weak category.

The result of the study is in accordance with Usman's opinion that work motivation is the desire or need underlying someone so that it is motivated to work (2009). Things that affect a person's work performance need to fulfill the two basic requirements first, namely (1) having the ability to achieve and (2) having the will to achieve (Rivai and Murni, 2009). While Simamora said that employee motivation to work, develop personal abilities, and improve abilities in the future is influenced by feedback on past performance and development (2000, p. 415).

\section{The effect of principal's situational leadership $\left(X_{1}\right)$ on work motivation $\left(X_{2}\right)$}

A teacher in doing his job well is often determined by an assessment of his performance. Assessment is not only done to help oversee organizational resources but also to measure the level of efficiency in the use of existing resources and identify things that need improvement. On the other hand, the Principal as a leader in formal education needs to have insight into the future. Basically the principal performs the following three functions, namely: helping teachers understand, choose, and formulate educational goals to be achieved, mobilizing teachers, employees, students, and community members to succeed education programs in schools, creating schools as a harmonious, healthy, dynamic, comfortable work environment so that all members can work with full productivity and obtain high job satisfaction. To instill the role of the school principal must show an exemplary attitude, this is what will color the leadership, including the guidance made by the headmaster of the teachers in the school. In its function as a driving force for teachers, principals must be able to move teachers so that their performance increases because the teacher is the spearhead for realizing quality human beings. The teacher will work optimally if supported by several factors including work motivation. The teacher becomes an educator because of the motivation to educate. If you do not have motivation, then he will 
not succeed in educating or if he is forced to teach and he does not have the will that comes from within the teacher. Motivation is one's potential force, which can be developed by himself, or developed by a number of external forces that are essentially around monetary rewards, and non-monetary rewards, which can affect the results of his performance positively or negatively. Teachers have potential energy reserves, how they will be released or used depending on the strength of the drive.

Based on the results of the $t$ test analysis, it shows the $t$ value of 7.502. This $t$ value is then compared with the value of $t$ table at a significant level with df 102 obtained a value of 1.984. After comparing it turns out that $t_{\text {value }}$ is greater than $t_{\text {table }}(7,502>1,984)$. Likewise with a significance level (p-value), in the table above it is known that the significance probability value (Sig.) $=0.02$. This means that the value of Sig $<\alpha$ value $(0.02<0.05)$, it can be concluded that $\mathrm{H}_{0}$ is rejected and $\mathrm{H}_{3}$ is accepted. So it can be concluded that the situational leadership of school principals has a significant effect on Kindergarten work motivation in Tangerang Regency. Correlation coefficient $\left(\mathrm{r}_{\mathrm{xy}}\right)$ between the principal's situational leadership $\left(\mathrm{X}_{1}\right)$ and work motivation $\left(\mathrm{X}_{3}\right)$ obtained a value of 0.598 with Sig. (2tailed) of 0.019 . This means the value of Sig. $(0,000)<\alpha(0.05)$. Coefficient value 0 is in the category of moderate correlation. Thus it can be concluded that the situational leadership of principals with work motivation has a significant relationship with the medium category.

Leadership is the generalization of a leader's behavior and leadership concepts, by highlighting the historical background, the causes of leadership, the requirements of leaders, the main nature of leaders, their main tasks and functions and the leadership professional ethics. Situational leadership is the activity of organizational leaders in their efforts to influence, encouraging, guiding, directing and moving teachers by approaching according to certain situations and the maturity level (maturity) of subordinates who are led. A person's motivation is influenced by intrinsic strength stimuli that exist in a person or individual concerned, external stimuli may also affect motivation, but motivation itself reflects the individual's reaction to these stimuli. Work motivation is the drive or enthusiasm that arises in a person or employee to do something or work, because of external stimuli from both the employer and the work environment, as well as the basis for meeting needs and feelings of satisfaction, as well as fulfilling responsibility for the tasks assigned and carried out in the organization.

Performance is the implementation of the functions demanded from a worker (Muljani, 2009). Performance also describes the greatest responsibility of one's work. In this way, performance can be said to be just the work, an act, and an achievement that is shown by someone through real skills, so that performance can also be interpreted as a work performance. Performance can be interpreted as an expression of one's potential in the form of a person's behavior or way of carrying out a task, so as to produce a product (work) which is a form of all the duties and responsibilities of the work given to him. On that basis, the performance is defined as the results of work achieved by a person or group of people 
in an organization according to their respective authorities and responsibilities in order to achieve the objectives of the organization concerned.

Referring to the formulation of the definition of performance, then the terminology of the teacher's work can be interpreted as a performance that is shown or the results achieved by a person or group of teachers in a certain period of time in carrying out the duties of education and teaching that has become the authority and responsibility of a group of teachers based on the procedures and rules that apply for the sake of achieving the goals that have been set. The teacher's performance is the actualization of his work in his role as educator, teacher, coach and mentor in carrying out learning and training tasks as a commitment to his profession.

The professional performance of teachers can be reviewed from competency in accordance with Law No. 14 of 2005 Chapter IV Article 10 concerning Teachers and Lecturers and Government Regulation No. 74 of 2008 Chapter II Article 3 concerning Competence and Certification, it is stated that there are competencies that pedagogic, competent, personal, competent and professional. According to Sudjana (2012), the teacher's performance can be seen from his competence in carrying out the tasks of the teacher, namely: planning the teaching and learning process, implementing and managing the teaching and learning process, assessing the progress of the learning process, and mastering the learning material.

Teacher performance is influenced by the leadership of the principal as stated by Wahyudi (2009), leadership as a person's ability to move, direct, and simultaneously influence the mindset, the way each member works to be independent in working, especially in making decisions for the sake of accelerating the achievement of the stated goals.

Basically leadership refers to a process to move a group of people towards something that has been set together by encouraging or motivating them to act in a way that is not compelling. Besides that leadership is also an ability to carry out work through other people by gaining trust and cooperation, almost all aspects of work are influenced and dependent on leadership. Situational leadership is a behavior-based theory of leadership (Zamroni and Umiarso, 2011). Situational leadership focuses on the commitment and capacity of organizational members. The increasing commitment and capacity of members is considered to produce greater effort and productivity and will be the outcome expected by an organization.

In a school organization, the Principal as a manager and at the same time as a leader has a big contribution to the smoothness of education under his leadership. The ability of the Principal to carry out education management needs to be mastered and increased considering the school as a business that produces products in the form of human resources and not products in the form of commodity goods. The Headmaster has a heavy burden on his shoulders because he has to lead several hundred students, teachers and administrative staff. This is a tough job that requires careful and careful thinking so that the Principal can lead subordinates and school residents with success. 
Situational leadership is based on interrelationship between the following: 1) the number of instructions and directions given by the leader, 2) the amount of emotional support provided by the leader, 3) the level of readiness or maturity of followers in carrying out specific tasks, functions or goals certain (Toha, 2013). In this case, the behavior of followers or subordinates is very important to know situational leadership because not only followers as individuals can accept or reject their leaders, but as followers can in fact determine whatever personal power the leader has. For this reason a leadership style is needed with directing behavior and supportive behavior. Directing behavior can be formulated to what extent a leader involves in one-way communication. This form of direction in one-way communication, among others, determines the role that followers should take, tells what should be done where to do this, how to do it and conduct strict supervision. Supporting behavior is the extent to which a leader involves in two-way communication, for example hearing, providing support and encouragement, facilitating interaction and involving followers in making decisions (Toha, 2013).

According to the contingency theory of Fiedler in Sujak (2010) successful leadership depends on the application of a leader's style to the demands of the situation. Application of leadership style, in the process of adaptation to the situation can take a process: (a) understanding the leadership style, (b) diagnosing a situation, and (c) applying leadership styles that are relevant to the demands of the situation. Site leadership makes leaders who successfully adapt their leadership style to the needs of the situation. In situational leadership there are four leadership styles that represent different combinations of leader's directive and supportive behaviors, which can be chosen in certain situations. Directing behavior is defined as how far a leader is involved in one direction: including the employee's role, and telling employees it's about things to do, where it must be done, when and how to do it; and then supervise the work carefully. Three words can be used to define directive behavior: structure, control and supervision.

Based on the description, what is meant by situational leadership is the Principal's activities in his efforts to influence, encourage, guide, direct and move the teacher by approaching according to certain situations and the maturity level of the subordinates who are led. Situational leadership by the Principal in this study consists of four indicators, namely: (1) The way the leader encourages teachers to excel, (2) The way the leader gives orders, instructions, (3) The way the leader gives encouragement and enthusiasm, and (4) The way the leader participate with subordinates.

Motivation cannot be observed directly, but it can be interpreted from the behavior. Motivation can be seen as a change in energy in a person characterized by the emergence of peeling, and previously thought of the purpose. Thus it can be summarized there are three notions, about motivation, namely (a) motivation to escort the change in energy in each individual, (b) motivation is marked by the feeling or feeling, one's affection. In this case, motivation is relevant to psychological, affective and emotional problems that can determine human behavior and (c) motivation is stimulated because of a goal. 


\section{CONCLUSIONS}

There are three findings from this research, namely there is a positive and significant direct influence of the principal's situational leadership on the performance of the Kindergarten teachers in the medium category; there is a direct positive and significant influence on work motivation on the performance of the Kindergarten teachers; and there is a positive and significant direct influence of the principal's situational leadership on the motivation of Kindergarten work in the medium category. It can be concluded from this findings that in improving teacher performance and work motivation, the leadership of school principals, particularly the appropriate style of leadership bring a profoundly impact the teacher's quality and school improvement, which contributes directly to student achievement. Change leaders are required to understand procedures and processes that create the conditions compulsory for organizational improvement. In addition, skilled leaders appropriately envision the needs of future and they must able to empower others to share and implement that vision, which bring success to the school organization.

\section{REFERENCES}

Arep, I \& Tanjung. (2010). Manajemen motivasi. Jakarta: PT. Grasindo.

Suharsimi, A. (2012). Prosedur penelitian: Suatu pendekatan praktek. Jakarta: PT.Rineka Cipta.

As'ad, M. (2008). Psikologi industri. Yogyakarta: Liberty.

Azwar, S. (2011). Metode penelitian. Yogyakarta: Pustaka Pelajar.

Burhanuddin. (2009). Analisis administrasi manajemen dan kepemimpinan pendidikan, Jakarta: Bumi Aksara.

Danim, S. (2010). Menjadi komunitas pembelajar: Kepemimpinan transformasional dalam komunitas organisasi pembelajaran. Jakarta: Bumi Aksara.

Daryanto. (2011). Kepala sekolah sebagai pemimpin pembelajaran. Yogyakarta: Gava Media.

Davis, K., \& Newstrom, J. W. (2010). Human behaviour at work. Translated by Agus Dharma. Jakarta: Erlangga.

Fatah, N. (2010). Landasan manajemen kependidikan. Bandung: Remaja Rosdakarya.

Fulan, M. (2002). The Change leader. Ontario: EBSCO publishing

Gaffar,F. (2007). Perencanaan Pendidikan. Jakarta: Depdikbud.

Ghozali, I. (2010). Aplikasi Analisis Multivariat dengan Program SPSS. Semarang: Badan Penerbit Universitas Diponegoro.

Gibson, J.L. et. al., (2008). Organisasi Perilaku, Struktur, Prose. Alih bahasa: Djarkasih, Jakarta: Erlangga.

Gomes, F.C. Manajemen Sumber Daya Manusia. Yogyakarta: Andi Offset. 
Hamalik, O. (2008). Manajemen Pengembangan Kurikulum. Bandung: PPs UPI dan Remaja Rosdakarya.

Hasibuan S. P. (2011). Manajemen, Dasar, Pengertian dan Masalah.Edisi Revisi, Jakarta: PT. Bumi Aksara.

Hersey, P. \& Blancard, K. (2007). Management of organizational behaviour. New Jersey: Englewood Cliffs.

Hidayat, A. \& Machali, I. Pengelolaan pendidikan, Bandung: Pustaka Educa.

Kast, F.E, \& Rosenzweig, J.E. (2012). Organisasi dan manajemen. Translated by A. Hasim Ali, Jakarta: Bumi Aksara.

Kelley, R.C., Thornton, B., \& Daugherty, R. (2005). Relationships between measures of leadership and school climate. Nevada: University of Nevada, College of Education. Department of Educational Leadership 1283. ProQuest Information and Learning Company. Retrieved from http://200.6.99.248/ bru487cl/files/ai_n.pdf

Kountur, R. (2009). Metode penelitian untuk penulisan skripsi dan tesis, Jakarta: Penerbit PPM.

Mangkuprawira, S.Tb. (2011). Manajemen sumber daya manusia strategic. Bogor: Ghalia Indonesia.

Muljani. (2009). Kinerja guru SLTPN di kota Banjarmasin. Thesis.Yogyakarta: UNY.

Mulyasa, E. (2012). Menjadi Kepala Sekolah profesional. Bandung: RemajaRosdakarya Offset.

Nasution, S. (2012). Berbagai pendekatan dalam proses belajar mengajar. Bandung: PT. Bumi Aksara.

Prasetyo, B, \& Jannah, L.M. (2005). Metode penelitian kuantitatif: Teori dan aplikasi. Jakarta: PT. Raja Grafindo Persada.

Purwanto, N. (2012). Administrasi dan supervisi pendidikan. Bandung: Remaja Rosdakarya.

Robbins, S.P. (2008). Organizational behaviour. Translated by Hadyana Pujaatmaka. Jakarta: Prenhallindo.

Ruky, A. S. (2007). Sistem manajemen kinerja. Jakarta: PT Bumi Aksara.

Sedarmayanti. (2011). Membangun dan mengembangkan kepemimpinan serta meningkatkan kinerja untuk meraih keberhasilan. Bandung: PT. Refika Aditama.

Sheltom, K. (2008). A New paradigm of leadership. Jakarta: Elexmedia Komputindo.

Siagian, S. (2012). Manajemen sumber daya manusia. Jakarta: PT Bumi Aksara.

Simamora, H. (2010). Manajemen sumber daya manusia. Cilegon: STIE YPKN.

Singarimbun, M. \& Effendi, S. (2010). Metode penelitian survei. Jakarta: LP3E.

Sudjana, N. (2008). Penelitian dan penilaian pendidikan. Bandung: Sinar Baru.

Sudjana, N. (2012). Dasar-dasar proses belajar mengajar. Bandung: Sinar Baru Algensindo. 
Sugiyono. (2010). Metode penelitian pendidikan. Bandung: Alfabeta.

Sugiono. (2012). Metode penelitian kuantitatif dan $R \& D$. Bandung: Alfabeta.

Sujak, A. (2010). Kepemimpinan manajer. Jakarta: Rajawali Pers.

Sulistiyani, A.T \& Rosidah. (2009). Manajemen Sumber Daya Manusia. Yogyakarta: Graha Ilmu.

Sulistiyani, A. T. (2008). Kepemimpinan profesional: Pendekatan leadership game. Yogyakarta: Gava Media.

Sulistyorini. (2009). Manajemen pendidikan Islam. Yogyakarta: Teras.

Terry, G. R. (2012). Principles of management, 6th edition, Illionis: Richard D. Irwin Homewood.

Thoha, M. (2013). Kepemimpinan dalam manajemen suatu pendekatan perilaku, Jakarta: Raya Srafindo Pustaka.

Umar, H. (2008). Metodologi penelitian untuk skripsi dan tesis bisnis. Jakarta: Grafindo Persada.

Uno, H.B. (2011). Riset manajemen sumber daya manusia dalam organisasi, Jakarta: Gramedia.

Usman, H. (2009). Manajemen, teori, praktik, dan riset pendidikan. Jakarta: Bumi Aksara.

Wahjosumidjo. (2011). Motivasi kerja. Jakarta: PT Rajagrafindo Persada.

Wahyudi. (2009). Motivasi kerja dalam organisasi pembelajar (Learning Organization). Bandung: Alfabeta.

Wibowo. (2012). Manajemen kinerja. Jakarta: PT. Raja Grafindo Persada.

Wukir. (2013). Manajemen sumber daya manusia dalam organisasi sekolah, First edition. Yogyakarta: Multi Presindo,.

Yusuf, A. E. (2012). Organisasi dan motivasi. Jakarta: RajawaliGrafindoPersada.

Zamroni \& Umiarso. (2011). ESQ model dan kepemimpinan pendidikan: Konstruksi sekolah berbasis spiritual. Semarang: RaSAIL.

Zamroni. (2013). Paradigma pendidikan masa depan. Yogyakarta: BIDRAF Publishing. 